\title{
How to lose the one you love
}

\author{
Out of sight, out of mind.
}

$\mathrm{F}$ irst off, the obligatory warning. Don't try this at home, kids! In the hands of inexperienced laymen, the method I am about to describe will inevitably be a disaster. Like, fatal-type disaster. Consider yourself forewarned.

That said, I have to admit that Jillian was truly one to die for. I'd never seen a woman whose visage struck me so deeply — smackdab in my gut, and various regions nearby. Whenever I saw her in the flesh, the Mormon Tabernacle Choir would insinuate itself into my brain, and I would reel in response to the ecstasy of her divine musical theme.

Many wise men throughout the ages have written about this sensation. Suffice it for me to say that, if she were a predator and I were her prey, I'd gladly give up my bodily organs for her to feast upon.

Unfortunately, that was never to be. Jillian didn't even know I existed. Complete bummer.

And why shouldn't that be the case? I was an experimental physicist and she a talented concert violinist. We had nothing at all in common between us, aside from the fact that we both lived in the same apartment building. Furthermore, judging from my surreptitious surveillance of her, she already had an intimate relationship with her orchestra's bassoon player. Even more of a complete bummer. In the time it would take me to become a competent enough bassoonist to challenge his role, all the protons in the Universe would have disintegrated.

It was a no-win situation.

Which is why I began to contemplate suicide.

Trouble was, I didn't want to die. All I wanted to do was to forget about Jillian, completely and irrevocably. Then I could

\section{$\rightarrow$ NATURE.COM}

Follow Futures: y @atureFutures f go.nature.com/ mtoodm move on with my life. It was a real dilemma. Just as it is, I'm sure, for a million other sociophobic nerds like me.
So here is where it gets a little complicated. Stay with me; don't sweat the physics stuff. It's not that hard to follow.

Quantum mechanics boils down to one simple principle: sometimes you win, sometimes you lose and sometimes you get rained out. You can't be sure of the result until you read about it in the sports section of the newspaper.

1) One big-assed electrical generator, capable of delivering instantaneous jolts of 20 or more amps on demand.

2) Two very large copper cables connected to the positive and negative poles of said generator, terminating in handgrips that you will grasp while standing barefoot in a tub of salt water.

3) A quantum trigger. An old radiumdial watch will do nicely.

4) A photomultiplier tube, to detect the random photons that emanate from the radium source.

5) A video camera, focused on the page of the telephone directory that lists the name of your love interest.

\section{6) A PC programmed} to fire off the generator's output when instructed by the quantum trigger, but also to cease firing when the video camera detects the disappearance of said name in the directory.

Simple, right? Remember, you both win and lose. The radium watch dial can either produce a photon within the computer's scanning cycle, or not. Both possibilities are real. The 'you' that survives this process will be the winner, set free, free, free. No more Jillian. No more love dilemma.

True, millions - possibly billions,

But that's just one interpretation - and there's every reason to believe it's the wrong one. We both win and lose. We go on to glory in one version of the Universe, and go down to ignominious defeat in another. (And, not to neglect the other possibility, we get soaking wet in a third.) The field of play is called the multiverse.

But you already knew that, right? Lately, it's all over TV, movies and the Internet. Few, however, realize that the concept is more than 50 years old. Sometimes it takes that long to agglomerate something into the popular zeitgeist.

It may be difficult to understand how we can exploit this fact to our personal benefit - but that's what this exposition is all about.

Like I said, don't sweat the small stuff. Bottom line, here's what you need to kludge together to solve the age-old problem of unrequited love: trillions, quadrillions - of yourselves will die to get there. But they're just bodies under the bridge.

Yet, it's not all so simple. The astute reader will question why and how I can refer to Jillian at all in my tale, when she has never existed in my current Universe.

The answer? I never pulled that quantum trigger. Call me a hopeless romantic, but I just couldn't envisage living in a Universe where I didn't love Jillian.

GARY CUBA'S speculative fiction has appeared in more than 50 magazines and anthologies, including Jim Baen's Universe, Flash Fiction Online, Daily SF and Grantville Gazette: Universe Annex. He lives in South Carolina with his wife and an inordinate number of freeloading critters. See thefoggiestnotion.com. 